\title{
Error Analysis of High School Students on Linear Program Topics Based on Newman Error Analysis
}

\author{
Hanne Ayuningtias Elsa, Eyus Sudihartinih \\ Study Program of Mathematics Education, Faculty of Mathematics and Natural Science \\ Education, Universitas Pendidikan Indonesia \\ e-mail: hanneaelsa@student.upi.edu; eyuss84@upi.edu
}

\begin{abstract}
This study aims to obtain a description of the errors of high school students on linear program topics by using the Newman Error Analysis. This type of research is a descriptive study with a qualitative approach. This research was conducted by giving a test to participants consisting of a three-word problem on the topic of a linear program then conducting interviews as a data collection technique. Participants in this study were five female students of class XI in one of the senior high schools in Bandung, including four people who were students majoring in Sciences studies and one person who was a student majoring in Social studies. Based on the results of a research according to the Newman Error Analysis, all participants made several types of errors on the topic of a linear program. Errors made by the participants include transformation errors made by three students, the process skill errors made by two students, and writing error answers made by two students.
\end{abstract}

Keywords: Qualitative; error; Newman Error Analysis; linear program; Senior High School.

\section{INTRODUCTIONS}

At the senior high school class XI, there were still some students who had difficulty understanding mathematics. One of the things that can cause students difficulties in learning mathematics is the difference in abilities possessed by each student. Errors in solving math problems can be used to find out the learning difficulties of mathematics experienced by students (Farida, 2015). This is important for teachers to be able to find out the location of student errors so they can know and anticipate learning difficulties experienced by students. One way that can be used to analyze student errors is by Newman Error Analysis (Halim \& Rasidah, 2019).

Table 1. Factors and Indicators of Student Error

\begin{tabular}{cll}
\hline No. & Factors Causing Student Error & \multicolumn{1}{c}{ Indicators } \\
\hline 1. & Reading & $\begin{array}{l}\text { Students are not able to interpret the purpose } \\
\text { of the problem, do not understand the } \\
\text { symbols or terms in the problem } \\
\text { Students do not understand the commands in } \\
\text { the problem } \\
\text { 2. Comprehension } \\
\text { Students are not able to make mathematical } \\
\text { models from information obtained from } \\
\text { problems } \\
\text { Students incorrectly perform arithmetic or } \\
\text { wrong operations on the steps that must be } \\
\text { performed to solve a problem } \\
\text { Students cannot or forget to write answers } \\
\text { based on commands on the problem, students } \\
\text { cannot write answers completely }\end{array}$ \\
\hline
\end{tabular}


In the curriculum 2013, one of the topics studied by students of class XI is a linear program. In Putri (2018), the linear program is one of the topics in compulsory mathematics subjects that contain several prerequisite concepts, including systems of linear equations, linear inequalities, and graphs. These concepts are indispensable in linear program topics and will be used in the following topics, namely on the topics of matrices, sequences and series, and polynomials. Linear programs can be used in everyday life to solve the problem of managing a limited resource to achieve an optimum goal, such as in the fields of economics, trade, industry, agriculture, and others (Putri, 2018).

Based on Suci's research (Andriyani \& Ratu, 2018), it was reported that students made errors in linear program topics, following examples of these errors.

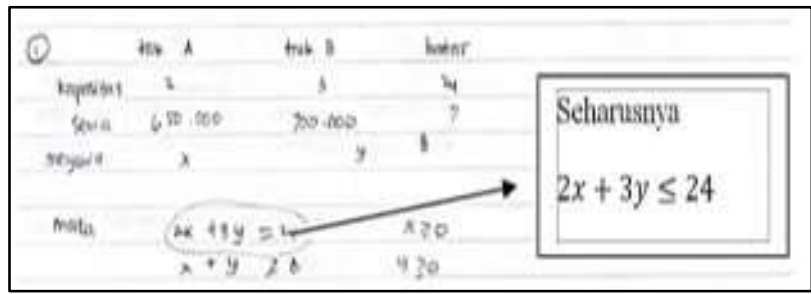

Figure 1. Error One

The error made by the student is an error in making a mathematical model. Figure 1 shows that students made an error in making the inequality that was asked for the problem.

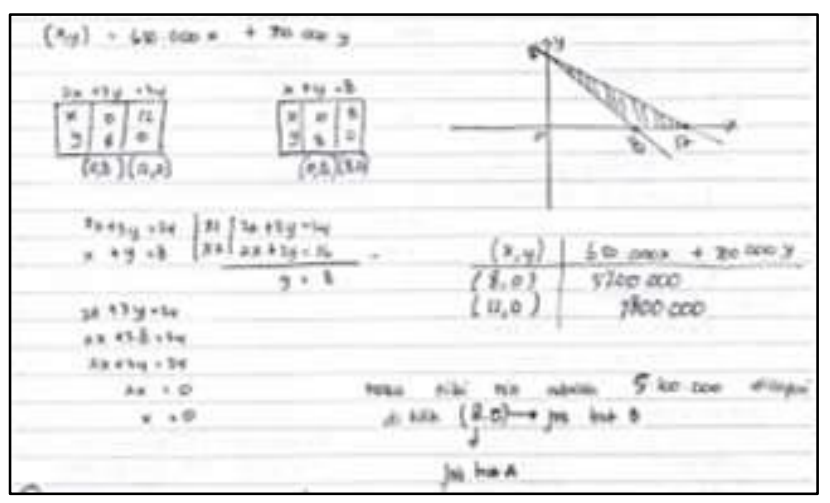

Figure 2. Second Error

The error made by the student is an error in determining the corner point, which is one of the methods used to find the optimum value of the objective function.

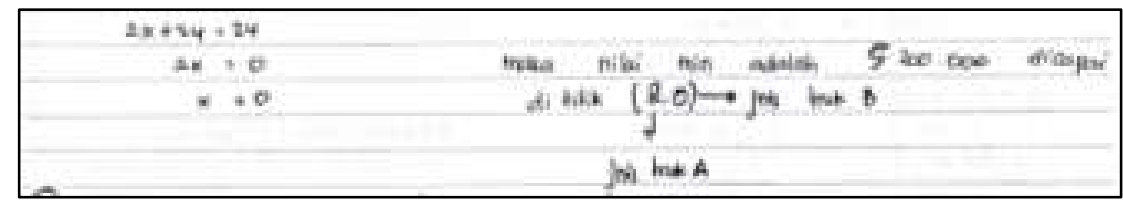

Figure 3. Third Error

The error made by the student is not appropriate in writing answers to the questions asked. According to Newman (Karnasih, 2015), Newman Error Analysis or NEA is used to help teachers identify students who have difficulty with word problems, provide students with experience in working on exercises, and hopefully, students can correct errors made in working on word problems. NEA is used to find out the underlying causes of difficulties 
for students, help teachers to determine the location of student errors, and determine effective learning strategies to overcome them (Karnasih, 2015). Based on these descriptions, researchers will examine the errors of senior high school students in linear program topics based on Newman Error Analysis.

\section{RESEARCH METHOD}

This study follows Sudihartinih's research (Sudihartinih, 2018), which is a descriptive qualitative study using data triangulation (interviews, documentation, and theory). The steps in this study are (1) providing tests in the form of story questions consisting of three items, (2) analyzing errors according to the NEA, (3) conducting interviews with students who make errors, and (4) documentation. Participants in this study were five 16-year-old students of the female sex and a Class XI student at one of the state high schools in Bandung. The participants consisted of one student majoring in social studies and four students majoring in science.

The instruments in this study were researchers, test questions, documentation, and interviews. In practice, this research took place in the school mosque and the time of its implementation after the learning and learning activities. Participants work on the questions individually (questions in Indonesian) for approximately 30 minutes followed by an interview. The problem in this study was arranged based on indicators (1) Students can determine the set graph of linear inequality system settlement, (2) Students can make mathematical models of story problems, and (3) Students can solve problems by applying linear program rules. The following questions are arranged based on these indicators in sequence as follows: (the source of these questions is derived from (Rohaeti, 2019) and (Gunarto, 2014))

1. Draw a graph that satisfies the linear inequality system

$$
\begin{aligned}
& x+y \leq 15 \\
& x+2 y \leq 20 \\
& x \geq 0, y \geq 0 \text { with } x, y \in R
\end{aligned}
$$

2. A property company will build two types of houses. For type 21 land area needed is $60 \mathrm{~m}^{2}$ and the type 36 land area needed is $90 \mathrm{~m}^{2}$. If the number of houses built is no more than 800 units and the area of land available is $54,000 \mathrm{~m}^{2}$, determine the inequality that satisfies the problem!

3. A tailor has a supply of $84 \mathrm{~m}$ of plain cloth and $70 \mathrm{~m}$ of batik cloth. The tailor will make two types of clothes for sale. Type A clothing requires $4 \mathrm{~m}$ plain cloth and $2 \mathrm{~m}$ batik cloth, while type B clothing requires $3 \mathrm{~m}$ plain cloth and $5 \mathrm{~m}$ batik cloth. If type A clothes are sold at a profit of Rp. 40,000.00 per piece and type B clothes are sold at a profit of $\mathrm{Rp}$. $60,000.00$ per piece, what is the maximum profit that the tailor can get? 


\section{RESULTS}

The following are the results of the tests conducted by participants, documentation, and interviews.

A. Student 1

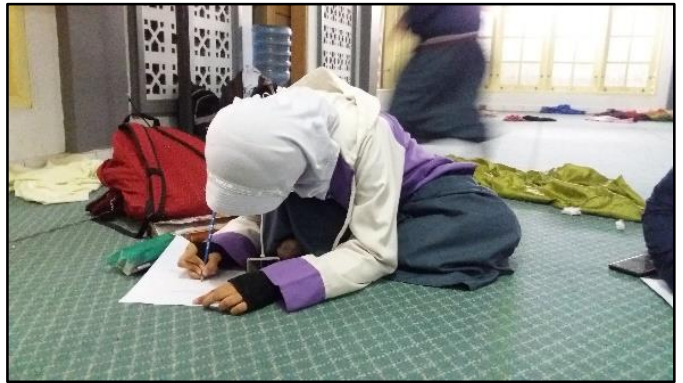

Figure 4. Student 1 when working on test questions

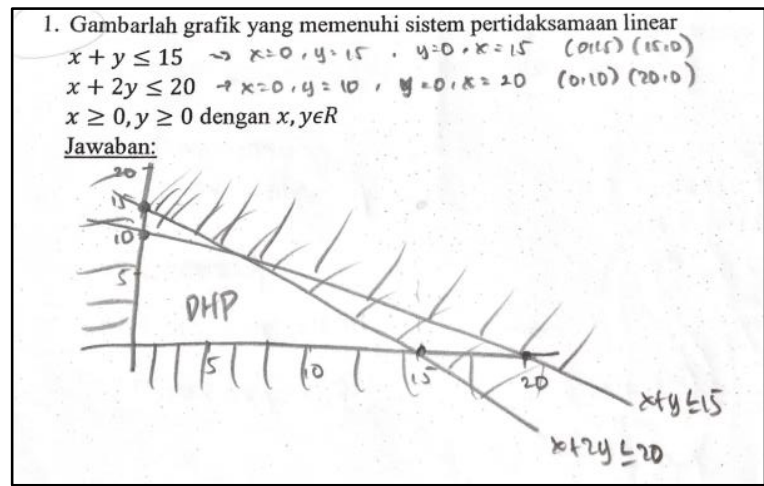

Figure 5. Student 1's Answer to question number 1

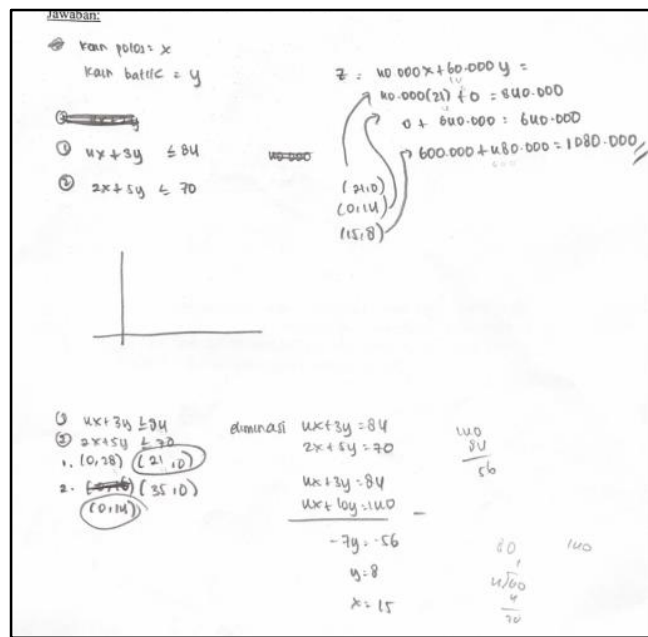

Figure 6. Student 1's Answer to question number 3

The interview for Student 1 on numbers 1 and 3 is as follows:

$\mathrm{P}$ : How can you be sure of this settlement set area? (while pointing at students' answers)

$\mathrm{S}$ : Because, first, test point ...

$\mathrm{P}$ : What point? 
$\mathrm{S}:(0,0) \mathrm{emm}$.. to this .. (pointing to answer) these two inequalities. And if for example, this does not meet the shaded one that does not meet, so if the clean one that meets so if for example later it is checked $(0.0)$ is true not less than 15 , later if for example shaded to .. to .. here, hehehe. (while pointing to the direction of shading)

$\mathrm{P}$ : So, which one is the answer to number 3 ?

S : Here is the answer, Rp1.080,000.00. Oh, I forgot to write the conclusion, Ma'am, hehehe.

Student 1 made a writing error answers to questions number 1 and 3 even though the calculation results were correct. In problem number 1, students do not write one way to draw a graph that is to test any point to determine the set of settlement areas that meet the inequality system. In question number 3, students are asked to write down the maximum number of benefits the tailor gets. However, students do not write their conclusions.

B. Student 2

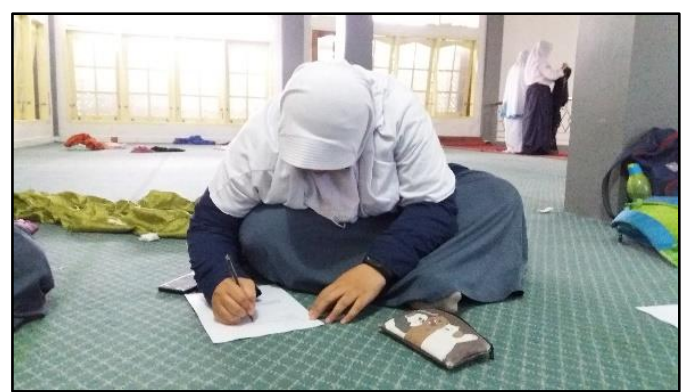

Figure 7. Student 2 when working on test questions

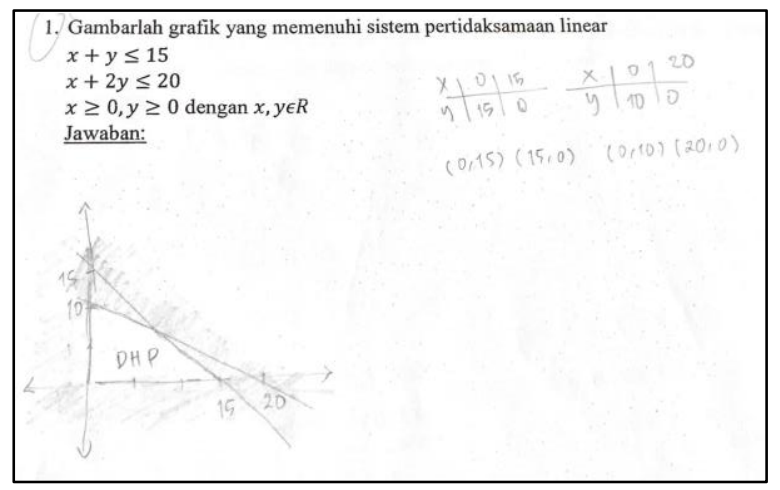

Figure 8. Student 2's Answer to question number 1

The interview on Student 2 on number 1 is as follows:

$P$ : How can you be sure that the settlement area is this one? (while pointing at students' answers)

S : Because I checked it, but I didn't write it.

$\mathrm{P}$ : How to checked it?

$\mathrm{S}:(0,0)$

P : What do you do with $(0,0)$ ?

S : subs $0 . .$. , because this like a line, the line looks like made territory. And $(0,0)$ that's a ... easy way to check for me. Now, $(0,0)$ is a mean point $(0,0)$. Well, then substituted to the first one, for example, $x=0, y=0$. Now that's less 
than 15 , it turns out that when I add up, oh right less than 15 means this is an area that I think is right. Then the second one is the same, I entered $(0,0)$ also because the example is easy.

Student 2 makes a writing error answer to problem number 1 . In this problem, students do not write one way to draw a graph that is to test any point to determine the set of settlement areas that meet the inequality system.

\section{Student 3}

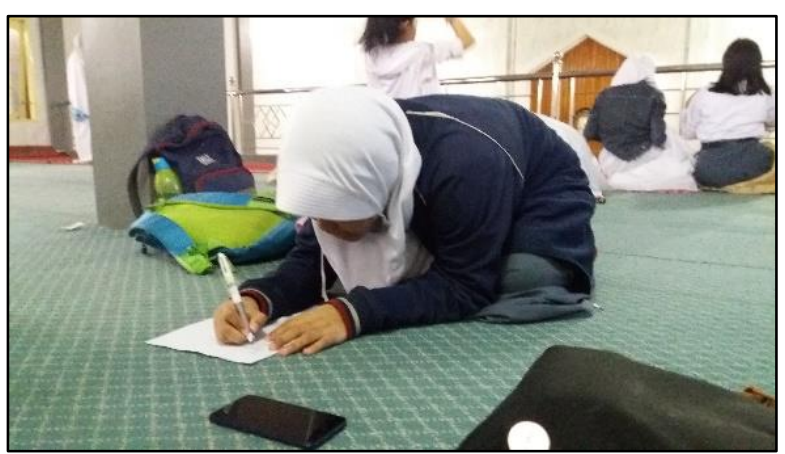

Figure 9. Student 3 when working on test questions

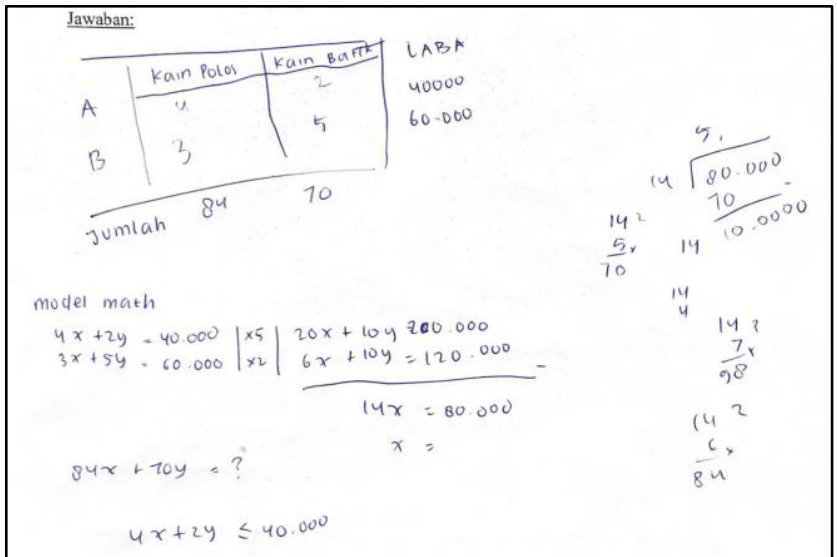

Figure 10. Student 3's Answer to question number 3

The interview on Student 3 on number 3 is as follows:

$\mathrm{P}$ : How do you do problem number 3?

$\mathrm{S}$ : I forgot to mention ma'am, just make the equation .. eh the inequality of the mathematical model.

$\mathrm{P}$ : Why is the mathematical model like that?

S : as long as hehehe (while scratching her head), I forgot it.

Students make an error transforming on problem number 3. In this problem, students are wrong in writing mathematical models. 
D. Student 4

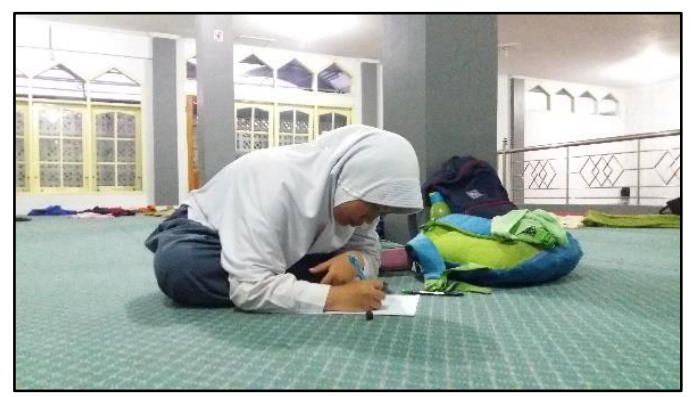

Figure 11. Student 4 when working on test questions

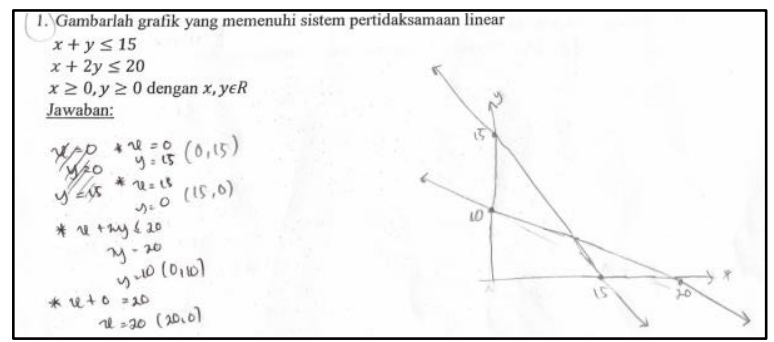

Figure 12. Student 4's Answer to question number 1

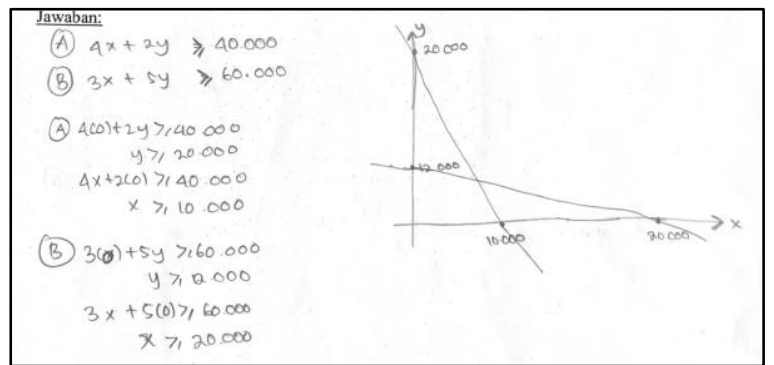

Figure 13. Student 4's Answer to question number 3

The interview for Student 4 in numbers 1 and 3 is as follows:

$\mathrm{P}$ : Why is the graphic like this? (while pointing at students' answers)

S : I am looking for the first intersection point with the second one, let's say that one of the points is 0 and then the intersection point

$\mathrm{P}$ : Then, which set of settlement areas?

S : Well, ma'am, I forgot to mention, so it's not continued (while scratching her head)

P : For number 3, how do you do the problem?

$\mathrm{S}$ : Make a mathematical model, ma'am, make the equation, then find the intersection point

$\mathrm{P}$ : Why is the mathematical model like that?

$\mathrm{S}$ : Actually, I'm still confused, ma'am, determining the $\mathrm{x}$ and $\mathrm{y}$ variables.

Student 4 made a process skill error on problem number 1 and the error transformed in problem number 3 . In problem number 1 , students did not write in full ways to draw a graph that is the stage of testing any point to determine the set settlement area and did not describe the graph in full. In problem number 3, students incorrectly write mathematical models. 


\section{E. Student 5}

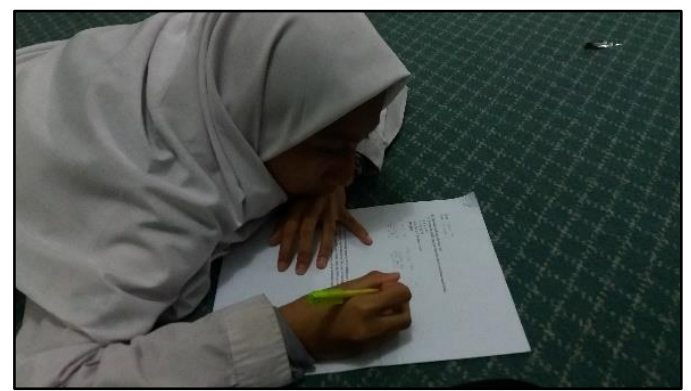

Figure 14. Student 5 when working on test questions

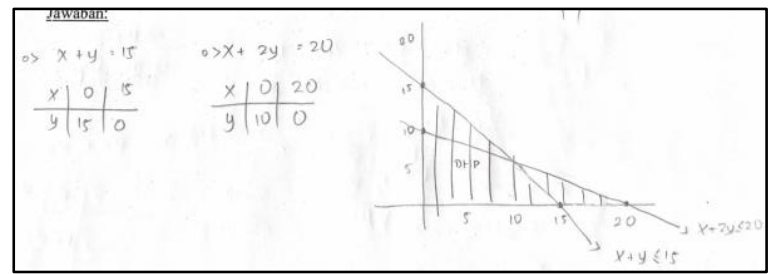

Figure 15. Student 5's Answer to question number 1

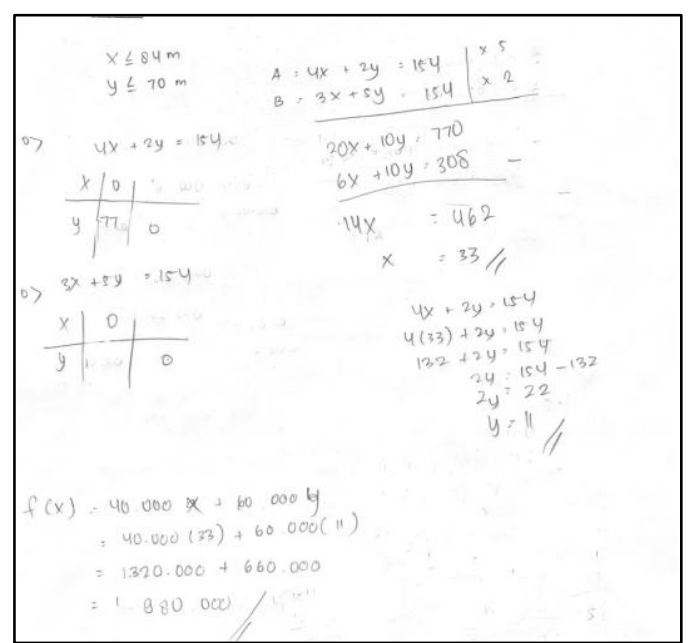

Figure 16. Student 5's Answer to question number 3

The interview on Student 5 in numbers 1 and 3 is as follows:

$\mathrm{P}$ : So, where is the settlement set?

$\mathrm{S}$ : This is, ma'am, which is shaded (pointing at the area), isn't that right, Ma'am?

$\mathrm{P}$ : Try to remember again, how to determine the settlement area?

S : For example, when tested, the point meets the means shaded like this (while pointing to the shaded area)

$\mathrm{P}$ : But, why only one inequality is shaded?

S : Oh yes ma'am, do I forget this one too? (designating the area that should be the settlement set area)

$\mathrm{P}$ : For number 3, how do you do the problem?

$\mathrm{S}$ : First, make the mathematical model, ma'am, then find $\mathrm{x}$ and $\mathrm{y}$, then substitute it into $\mathrm{f}(\mathrm{x})$

$\mathrm{P} \quad$ : Why is the mathematical model like that? 
$\mathrm{S}$ : Suppose that $\mathrm{x}$ is plain and $\mathrm{y}$ is batik. Then the supply is $84 \mathrm{~m}$ and $70 \mathrm{~m}$ so there are $154 \mathrm{~m}$.

Student 5 made a process skill error on item number 1 and error transformed in item number 3. In item number 1 , students did not write in full ways to draw a graph that is the stage of testing any point to determine the set settlement area and incorrectly assessing the area settlement set on the graph. In problem number 3, students incorrectly write mathematical models.

From this description, an error data is obtained according to the NEA, i.e.: Table 2. Categorizing Student Errors

\begin{tabular}{cccc}
\hline $\begin{array}{c}\text { Participant } \\
\text { s }\end{array}$ & Number 1 & Number 2 & Number 3 \\
\hline Student 1 & Error 5 & True & Error 5 \\
Student 2 & Error 5 & True & True \\
Student 3 & True & No Answer & Error 3 \\
Student 4 & Error 4 & No Answer & Error 3 \\
Student 5 & Error 4 & True & Error 3 \\
\hline Note : Error 3: transformation errors & & \\
& Error 4: process skill errors \\
& Error 5: writing error answers & &
\end{tabular}

The same errors were discovered by (Ellerton \& Clements, 1992), who stated that there were transformation errors, process skill errors, and writing error answers, but the study was conducted on Grade VII students with a different topic from this study. To minimize student errors, teachers can make improvements in the learning process, one of which is to emphasize the concept of students and guide and motivate students to practice answering questions. For students, they should tell the difficulties experienced in the learning process to the teacher or ask friends who are more in charge of the topic (Indra Puspita Dewi, Wisna Ariawan, \& Gita, 2019).

\section{CONCLUSION}

The conclusion in this study is that there are student errors in linear program topics. Based on Newman Error Analysis, the transformation errors are made by three students, the process skill errors are made by two students, and the writing error answers are made by two students. Errors made by students are caused by a lack of understanding of the concept of a linear program and forgetting to write answers in full so that efforts can be made to reduce these errors by designing teaching materials or choosing appropriate learning strategies.

\section{REFERENCES}

Andriyani, A., \& Ratu, N. (2018). Soal Cerita Pada Materi Program Linear Ditinjau Dari Gaya Kognitif Siswa. Jurnal Pendidikan Berkarakter, 1(1), 16-22.

Ellerton, N., \& Clements, M. a. (1992). Implications of Newman research for the issue offn"What is basic in school mathematics?". 276-284. Retrieved from http//www.merga.net.au/documents/MERJ_7_1_Mitchelmore\&White.pdf\%5Cn 
http $/ /$ docs.google.com/viewer?a=v\&q=cache:an-

TYsBzWUcJ:www.merga.net.au/publications/counter.php?pub=pub_conf\&id=1

$048+\% 22$ remedial+mathematics $\% 22 \& \mathrm{hl}=\mathrm{en} \& \mathrm{gl}=\mathrm{au} \& \mathrm{pid}=\mathrm{bl} \& \mathrm{srcid}=\mathrm{ADGEESig}$

IgQhKAB1c

Farida, N. (2015). Analisis Kesalahan Siswa SMP Kelas VIII dalam Menyelesaikan Masalah Soal Cerita Matematika. Jurnal Pendidikan Matematika FKIP Universitas Muhammadiyah Metro, 4(2), 42-52. https://oi.org/10.1145/3132847.3132886

Gunarto, P. A. (2014). Big Bank Soal + Bahas Matematika SMA/MA Kelas 1, 2, \& 3. Jakarta: Wahyu Media.

Halim, F. A., \& Rasidah, N. I. (2019). Analisis Kesalahan Siswa Dalam Menyelesaikan Soal Cerita Aritmatika Sosial Berdasarkan Prosedur Newman. Jurnal Pendidikan Matematika, 02(01), 35-44.

Indra Puspita Dewi, K., Wisna Ariawan, I. P., \& Gita, I. N. (2019). Analisis Kesalahan Pemecahan Masalah Matematika Siswa Kelas Xi Sma Negeri 1 Tabanan. Jurnal $\begin{array}{llll}\text { Pendidikan Matematika Undiksha, } & \text { 10(2), }\end{array}$ https://doi.org/10.23887/jjpm.v10i2.19917

Karnasih, I. (2015). Analisis Kesalahan Newman Pada Soal Cerita Matematis (Newman'S Error Analysis in Mathematical Word Problems). Jurnal Paradikma, 8(April), 3751. Retrieved from http://digilib.unimed.ac.id/1368/2/Full Text.pdf

Putri, I. S. (2018). Desain Didaktis Pembelajaran Matematika untuk Mengatasi Hambatan Epistimologi pada Konsep Program Linear di SMA. https://doi.org/10.1017/CBO9781107415324.004

Rohaeti, E. E. (2019). Pembelajaran Inovatif Matematika. Bandung: Refika Aditama.

Sudihartinih, E. (2018). Analisis Kesalahan Siswa Dalam Konsep Titik Dan Garis Pada Bidang. Erudio Journal of Educational Innovation, 5(1), 12-18. https://doi.org/10.18551/erudio.5-1.2 